\title{
Editorial: Developing Writing in STEM Disciplines
}

\author{
Trevor Day \\ University of Bath, UK \\ John Hilsdon \\ Plymouth University, UK \\ Andy Hagyard \\ University of Lincoln, UK
}

The first Special Edition of the JLDHE, published in 2010, was a collection of papers written as part of the National Action Research Network project on PDP and e-Portfolio Practice, and was called "Researching and Evaluating Personal Development Planning and e-Portfolio Practice". The second Special Edition is also a collaborative venture. It was prompted by the National HE STEM Programme project Developing Writing in STEM Disciplines (http://go.bath.ac.uk/stemwriting) which ran throughout 2010-11. Its follow-up activities (of which this special edition is one) are extending into 2013. The project was responding to the issue of graduate literacy, with surveys such as those of the Association of Graduate Recruiters (Graduate Prospects, 2008) and the Council for Industry and Higher Education (Archer and Davison, 2008) identifying the writing abilities of graduates as a key area for concern.

Learning developers are acutely aware of the importance for students of acquiring the successful habits, and adopting the socially approved codes, of written language in their chosen discipline. The theme of developing the capabilities to write successfully is a very important one, especially given the extent to which value is attached to the appropriate use of language in education and employment. For this reason it is important that we explore how students can develop successful practices for their context and discipline.

The HE STEM project supported initiatives aiming to identify and respond to concerns about writing in the science, technology, engineering and maths disciplines and, if there were needs to address, what form appropriate responses might take. 
In its response to this agenda, the 'Developing writing in STEM disciplines' project adopted two approaches. The first, a research strand, explored the views and experiences of engineering undergraduates, industrial supervisors and faculty staff in relation to writing development and employability. In the second strand, involving the setting up of a collaborative network, the project's seven partner universities (Bath, Coventry, Exeter, Limerick, Oxford Brookes, Plymouth and West of England) shared their writing-related research findings and good practice. The findings and identified good practice were then disseminated through conferences and workshops, and prompted the setting up of a National HE STEM-funded special interest group 'Writing and Communicating in STEM Disciplines' (http://go.bath.ac.uk/stemwritingandcommunicatingsig). Through the various activities, the project identified evidence-led, writing-related issues that applied to the graduate employability agenda and suggested writing development practices that would be effective responses.

In the project, analysis of interviews and questionnaire survey responses from Engineering students, industrial supervisors and faculty staff suggested the prevalence of an instrumental, skills-driven agenda for writing development, with students becoming socialised into the writing conventions of their discipline. This, to some extent, contrasted with the more contested forms of disciplinary discourse encouraged by many writing developers, which are often influenced by academic literacies theory (Lea and Street, 1998) and constructs of identity and authorial presence (Ivanic, 1995; Lillis, 1997, 2001).

The project's second strand, in responding to such findings, identified a range of responses, including: promoting 'Writing in the Disciplines' (WiD) approaches (Deane and O'Neill, 2011; WAC Clearinghouse, 2012) with learning developers and writing specialists working alongside subject specialists to embed writing practice within the disciplinary curriculum; introducing and/or demystifying writing-related assignment guidelines and assessment criteria; multi-dimensional diagnostic instruments for assessing students' writing; creative use of prompt material, such as newspaper articles, project reports, legal case studies and other work-related documents; use of online technologies to support both academic and employment-related writing; students writing collaboratively; and recognition that academic and broader employability needs can be met within a disciplinary curriculum at one and the same time. Many of these approaches are considered by the breadth of papers in this special edition of the JLDHE. 
This edition is a response to the underreporting of writing development practice in STEM disciplines in the UK, and especially that relating to collaboration between STEM subject specialists and various kinds of learning developer, including writing and language specialists. In that respect, the 10 papers and case studies in this edition represent a cross-section of that spectrum, with papers written by subject specialists, others by learning developers of various kinds, and some as collaborative partnerships between the two.

In eastern Australia, collaborative approaches between learning developers and disciplinary specialists have been at the forefront of internationally-recognised writing development initiatives for at least two decades. Building on this practice, Drury and Mort give an account of the Write Reports in Science and Engineering (WRiSE) project and its online resource, which contains modules drawing upon eight STEM disciplines. This resource is accessed by thousands of undergraduate students in Australia and beyond, and there is a strong evidence base for its success. Amos and McGowan offer a potential model for collaboration between a writing specialist and subject teacher in STEM disciplines. Their account describes the application of genre pedagogy, encouraging students to develop their own academic writing by analysing a particular genre from their own discipline.

Two case studies report on fine-tuning improvements in writing interventions over one or more years, with subject specialists working with writing developers or language specialists. Narduzzo and Day report on a small-scale WiD intervention in Physics, employing peer assessment, which shows how an undergraduate student assignment can yield rich returns in terms of helping students to acclimatise to academic writing practices. Through analysing qualitative and quantitative data on the process and product of the assignment, they show how small-scale research can productively inform curriculum development in a STEM discipline. Armstrong, Dannatt and Evans give an account of their collaboration between an English Language Centre and an Electronic and Electrical Engineering Department in meeting the writing needs of first year undergraduates and visiting Chinese second year students.

Of course, writing development is just part - albeit a key part - of students' learning development and preparation for employment after graduation. Appleby, Roberts, Barnes, Qualter and Tariq address some aspects of writing development at the 
transitional stages from school/college to university, through university, and then on to employment. Based in part on evidence from student, alumni and employer interviews, they argue for the importance of social learning and writing development within a 'learning to learn' agenda. Bernaschina and Smith provide a case study examining how teaching about writing can be embedded in the first year curriculum. They describe issues arising from an initiative by their School of Science and Technology that seeks to integrate skills for writing into the wider employability skills framework.

Simonite's case study on data-driven journalism in mathematics disciplines makes clear links between developing writing capabilities and employability. Through a review of students' practices, as reported in online feedback, she reveals benefits and challenges of asking students to research and analyse data and communicate it meaningfully to a nonspecialist audience using writing and graphics.

Bowman and Cullen describe the impact of weekly written tasks on the quality of computing students' final year projects. In addition to reporting a positive correlation between engagement with the tasks and the standard of completed reports, the paper concludes with some recommendations for further 'learning through writing' activities.

For mathematical writing, Samuels proposes four methods for capturing advanced mathematical activity that can inform both the creative process and subsequent reporting of outputs. This paper highlights how written text interacts closely with other forms of representation, a feature also common to other STEM subjects.

Giminez considers students writing collaboratively - something engineers and scientists commonly do in their professional practice. He reviews various sources of evidence (observation notes, text analysis, 'talk around text' and interviews) gathered from 21 students and four academics across four schools of Engineering. Giminez proposes that planning and composing can be orchestrated for a group through the use of technological tools (especially online), and he explores some of the pedagogical implications of doing so.

We hope that this special edition of the JLDHE will stimulate further interest in research and the shaping of good practice in the field of STEM writing. This small collection captured some snapshots of the wide range of approaches being applied in STEM writing 
development. As well as adding to the evidence base and discussion in support of embedding effective practice, it also highlights the value of practitioners from different disciplines and perspectives coming together. Points of friction generate heat, but also light that provides some illumination. Partnerships between STEM academics and learning developers can help transform the practice of both groups, enhancing the student experience and contributing to them developing socially and economically valued skills. This coming together of a wide range of practitioners, with various voices and pedagogic perspectives, was also a hallmark of the original project. It is an emerging community of practice that is vital to help ensure that students' writing development is given the attention it deserves, and in responding to this impetus, effective and collaborative pedagogic practices are embedded, not simply 'bolted' on to, undergraduate STEM programmes.

\section{References}

Archer, W. and Davison, J. (2008) 'Graduate Employability: What do employers think and want?' Report for the Council for Industry and Higher Education (CIHE). London: CIHE

Deane, M. and O'Neill, P. eds. (2011) Writing in the Disciplines. Basingstoke: Palgrave Macmillan

Graduate Prospects (2008) 'Graduate recruitment in 2008 and outlook for 2009.' Manchester: Graduate Prospects. Available from:

http://www.prospects.ac.uk/cms/ShowPage/p!epkmfjX [accessed 28 August 2012]

Ivanic, R. (1995) 'Writer identity.' Prospect: The Australian Journal of TESOL, 10 (1), pp. 8-31.

Lea, M.R. and Street, B.V. (1998) 'Student writing in higher education: an academic literacies approach'. Studies in Higher Education, 23 (2), pp. 157-172

Lillis, T.M. (1997) 'New voices in academia? The regulative nature of academic writing conventions'. Language and Education, 11 (3), pp. 182-199

Lillis, T.M. (2001) Student Writing: Access, Regulation, Desire. London: Routledge. 
WAC Clearinghouse (2012) An Introduction to Writing Across the Curriculum and What is Writing in the Disciplines? Fort Collins, CO: Colorado State University. Available from: http://wac.colostate.edu/intro/ and http://wac.colostate.edu/intro/pop2e.cfm respectively [accessed 28 August 2012]

\section{Acknowledgements}

We are indebted to Fran Laughton, Director of the HE STEM Programme South West (http://www.hestem-sw.org.uk/about/south-west-spoke/) who arranged co-funding for this special edition and who supported the original project together with other members of her team: Sarah Chatwin, Alana Coyle, Ed Stevens and Ruth Waring. The original Developing Writing in STEM Disciplines project members, in addition to two of us (JH and TD), were Karen Bultitude, Barrie Cooper, Rachel Canter, Lawrence Cleary, Mary Deane, Lisa Ganobscik-Williams, Ide O'Sullivan and Margarida Sardo. We are grateful for their gracious willingness to share their, often inspirational, good practice. Four of them (BC, RC, LC and LGW) kindly contributed their editorial insight to this special edition. We also wish to thank those referees - who must remain anonymous - who invested their time and expertise in peer reviewing the papers. And finally many thanks to Natalie Bates for proofreading the final manuscripts. 